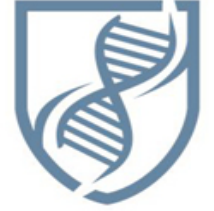

Journal of Bioscience and Applied Research

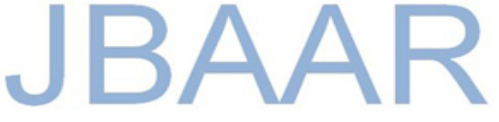

WWW.JBAAR.ORG

\title{
Antitumor activity of two Streptomyces extracts (Ag18 \& Ag20) on Ehrlich ascites tumor in mice: in vitro and in vivo studies
}

\author{
Amany A. Gaber ${ }^{1}$, Osama M. Badr ${ }^{2}$, Saad A. Emara ${ }^{3}$, Atef M. Ibrahim ${ }^{1}$ \\ 1.Microbial Biotechnology Department, Genetic Engineering \& Biotechnology Institute, \\ Sadat city University, Sadat City, Egypt \\ 2.Animal Biotechnology Department, Genetic Engineering \& Biotechnology Institute \\ Sadat City University, Sadat city, Egypt \\ 3. Cytology \& Histology Department, Faculty of Veterinary Medicine \\ Sadat city University, Sadat city, Egypt \\ (Corresponding author Email: osama.badr@gebri.usc.edu.eg)
}

\begin{abstract}
This study aimed to evaluate the potent antitumor activity of metabolites from Streptomyces as antitumor activity using in vitro and in vivo studies. The Streptomyces were purely isolated from the soil samples, recultured and processed to obtain their extracts. Twenty Streptomyces extracts were obtained. Two isolates of Streptomyces were characterized morphologically, physiologically, biochemically and 16sr RNA and they named Streptomyces strain Ag18 and Streptomyces strain Ag 20. Twenty four female albino mice were used in the present study. The mice were divided into 4 groups (6 animals each). The $1^{\text {st }}$ was control, injected subcutaneously with an isotonic saline solution. The $2^{\text {nd }}$, injected subcutaneously with Ehrlich ascites tumor cells (EAC). Both the $3^{\text {rd }}$ and $4^{\text {th }}$ group were injected subcutaneously with Ehrlich ascites tumor cells (EAC) diluted with an isotonic saline solution (SS); after tumor formation, (7-10) days after inoculation with EAC cells, animals were locally injected subcutaneously with Streptomyces extract, Ag18 and Ag20.The results revealed that only two of the twenty Streptomyces extracts (Ag18 and $\mathrm{Ag} 20$ ) showed their potent antitumor activity against Ehrlich ascites carcinoma cells in vitro. AG18 and AG20 Streptomyces extracts also modulated the mice body weight towards the normal values significantly $(\mathrm{p}<0.001)$ and reduced the tumor volume with a very highly significant change $(p<0.001)$. The histological study confirmed the above mentioned result, where the kidney and liver of the mice injected with EAC returned to their normal structure after injection with Streptomyces extracts.
\end{abstract}

It is concluded from this study that bioactive product ofStreptomycesAg18 \& Ag20 have antitumor activity.

Keywords: EAC (Ehrlich Ascites Carcinoma) cells,

Histological studies, in vitro \& in vivo studies, Mice,

Streptomyces Ag18 \& Ag20.

\section{Introduction}

Streptomycetes are filamentous Gram-positive bacteria belonging to the phylum Actinobacteria that represents one of the largest taxonomic units among the 18 major lineages currently recognized within the domain Bacteria (Ventura et al., 2007). Actinobacteria are widely distributed in terrestrial and aquatic ecosystems, especially in soil. They are important in soil biodegradation and humus formation by the recycling of nutrients associated with recalcitrant polymers such as keratin, lignocelluloses and chitin (Goodfellow and Williams, 1983; Stach and Bull, 2005) and produce several volatile substances like geosmin responsible of the characteristic "wet earth odor" (Wilkins, 1996). They also exhibit diverse physiological and metabolic properties, such as the production of extracellular enzymes (McCarthy and Williams, 1992; Schrempf, 2001). Recently drug discovery from streptomycetes by using high-throughput screening and fermentation, have attracted great attention. In addition, in the last years the isolation of marine streptomycetes has been a great source of new compounds, especially antitumor substances (Bernan et al., 2004). Most of the cancer chemotherapy drugs have undesirable side effects, for that increase the demand for 
novel antitumor drugs (Demain and Davies, 1999). A great number of antitumor compounds are natural products or their derivatives, mainly produced by microorganisms. The antitumor antibiotics produced by Streptomyces are invaluable in the medical field (Mueller and Nicole 2002; Azambuja et al., 2005). Lam et al., (1990) and Leet et al., (1990) recorded that Himastatin which is an antibiotic isolated from fermentation broths of Streptomyces hygroscopicus; had an antimicrobial activity against gram positive bacteria and was cytotoxic to mammalian tumor cell lines in vitro.L-Asparaginaseis the first enzyme produced from Streptomyces had an antitumor activity intensively studied in human beings (Savitri and Azmi, 2003). It is used for the treatment of malignancies of the multiorgans (Kumar and Selvam, 2011). It is used widely as a therapeutic agent for treating acute lymphoblastic leukemia in children and lymphosarcoma (Khamna et al., 2009).

There are few literatures on the effect of Streptomyces on tumor cells. So that the present study aimed to study the antitumor effect of Streptomyces extracts in vitro and in vivo against Ehrlich Ascites carcinoma (EAC) cells.

\section{Materials and Methods}

\section{Soil sampling sites and isolation of Streptomyces}

Soil samples were collected from various locations of the Tamalay village, Menoufia Governorate, Egypt from 2008 to 2009; samples were randomly collected on sites at a distance of $2 \mathrm{~km}$ apart from each other within the accessible areas. Soil samples ( $2 \mathrm{~g}$ per site) were randomly collected from the open land, and under the shrubs and trees. Soil samples were taken from the top $(7.5-10 \mathrm{~cm})$ of the soil profile using a sterile sample collection corer, put in sterile soil sample bags and kept in a box for transportation to the laboratory, where they were subsequently stored at $4^{\circ} \mathrm{C}$.

The soil was pretreated with $\mathrm{CaCO}_{3}(10: 1 \mathrm{w} / \mathrm{w})$ and incubated at $37^{\circ} \mathrm{C}$ for 4 days. It was then suspended in sterile Ringer solution (1/4 strength). Test tubes containing a 10-2 dilution of the samples were placed in a water bath at $45^{\circ} \mathrm{C}$ for $16 \mathrm{~h}$; so that the spores would separate from the vegetative cells and the dilutions were inoculated on the surface of the Actinomycete isolation Agar plates. The plates were incubated at $28^{\circ} \mathrm{C}$ until the sporulation of Streptomyces colonies occurred. Streptomyces colonies (where the mycelium remained intact and the aerial mycelium and long spore chains were abundant) were then removed and transferred to the Yeast Extract-Malt Extract Agar (ISP2) slants. Pure cultures were obtained from selected colonies for repeated sub culturing. The isolated Streptomyces strains were maintained as suspensions of spores and mycelial fragments in $10 \%$ glycerol $(\mathrm{v} / \mathrm{v})$ at $20^{\circ} \mathrm{C}$ in the Genetic Engineering and Biotechnology Institute (GEBRI).
Streptomyces cultivation media composition and extracts

Antibiotic Medium was used for the cultivation of the test Streptomyces and has the following composition: [Yeast extract $5 \mathrm{~g} / 1$, Ammonium sulphate $0.5 \mathrm{~g} / 1$, Glucose $10 \mathrm{~g} / \mathrm{l}$, Peptone $10 \mathrm{~g} / 1$, Sodium chloride $10 \mathrm{~g} / \mathrm{l}$, and Agar $25.0 \mathrm{~g} / \mathrm{l}$ ]. These media were prepared according to the manufacturer instructions.

The maximum secretion of metabolites from the strain was found at the $14^{\text {th }}$ day of incubation in yeast extract sucrose agar (alkaline $\mathrm{pH}$ 8.6) medium at $37.5^{\circ} \mathrm{C}$ by maintaining all the physicochemical factors at optimum level for the culture. The extraction of the metabolites was carried out by ethyl acetate on the basis of best solubility and maximum antimicrobial activities. The solvent; ethyl acetate was evaporated using a rotary evaporator at $40^{\circ} \mathrm{C}$ under reduced pressure. On average; $1 \mathrm{~L}$ of culture filtrate gave $2.5 \mathrm{mg}$ of crude extract.

\section{Characterization of the isolates}

Streptomyces colonies were characterized morphologically and physiologically following the directions given for the International Streptomyces Project (ISP) (Shirling and Gottlieb, 1966). General morphology was determined using the Oatmeal Agar plates, incubated in the dark at $28^{\circ} \mathrm{C}$ for 21 days and then by direct light microscopy examination ofthe surface of the cross-hatched cultures. Colors were determined according to the scale adopted by Prauser (1964). Melanin reactions were detected by growing the isolates on Peptone-Yeast Extract-Iron Agar (ISP 6) (Shirling and Gottlieb, 1966). All strains were cultivated on an ISP 2 medium. Some diagnostic characters of highly active Streptomyces strains were determined following the directions given in the Bergey's Manual of Systematic Bacteriology.

\section{Morphological Characterization}

Streptomyces colonies on glycerol-nitrate-casein agar were transferred onto oatmeal agar and streaked across the plate and incubated in the dark at $27^{\circ} \mathrm{C}$ for 21 days. The criteria are investigated as follows:

Color Determination; this made for: a) Mass color or mature, sporulating aerial surface growth, b) The color of substrate mycelium as viewed from the reverse side, and c) Diffusible soluble pigments other than melanin. Observation was made after 21 days and was limited to mature cultures with heavy spore mass surface using code for determining the color of aerial mycelium of Streptomycetes composed by Prauser (1964) for color tabs of Baumann Farbtonkarte Atlas.

Morphology of Spore Bearing Hyphae; the sporebearing hyphae characteristics were determined by direct microscopic examination of the culture surface (21 days old) on opened dishes of the crosshatched cultures using 
$100 \mathrm{x}$ magnification. The species involved in the genus Streptomyces divide into sections: Rectus (R) or straight, flexible (F) or flexeous, Retinaculum-Apertum (RA) and spiral (S).

\section{Physiological Characterization:}

The criteria which investigated are as follows: Melanin Production; Peptone iron agar was used for the detection of deep brown to black diffusible pigment $(+)$; absence of the color was recorded as negative (-).Carbon Utilization; the following sugars were tested, L-arabinose, D-xylose, meso- inositol, D-mannitol, D-fructose, rhamnose, raffinose and sucrose. Preparation was done as described in the ISP (Shirling and Gottlieb, 1966). Characterization of Streptomyces sp. strain AG18 and AG20 to species level was based on morphological, cultural and physiological characteristics following the directions given for the International Streptomyces project (ISP) (Shirling and Gottlieb, 1966).

General morphology was determined on oatmeal agar plates, incubated in the dark at $27^{\circ} \mathrm{C}$ for 21 days, by direct light microscopy examination of the surface of crosshatched cultures. Colors were determined according to the scale adopted by; Prauser (1964) and melanin reactions were detected by growing the isolate on at least one of the ISP media (Nos. 6 and 7).

\section{DNA Extraction}

Total genomic DNA from Streptomyces used in this study was isolated using DNeasy Blood \&Tissue Kit (Qiagen) according to manufacturer's protocol(Innis et al., 1990).

\section{PCR amplification of PKS and NRPS-genes}

Bacterial modular type I PKS genes were amplified with the degenerate primers KSMA-F (5'-TS GCS ATG GAC CCS CAG CAG-3') and KSMB-R (5'-CC SGT SCC GTG SGC CTC SAC-3'). PCR with these primers, amplifying the $\beta$-ketoacyl synthase (KS) domain ( 700 bp), was performed using initial denaturation at $96{ }^{\circ} \mathrm{C}$ for $5 \mathrm{~min}, 35$ cycles of $95{ }^{\circ} \mathrm{C}$ for $1 \mathrm{~min}, 60^{\circ} \mathrm{C}$ for $1 \mathrm{~min}$ and $72^{\circ} \mathrm{C}$ for 2 min. Final extension was performed at $72{ }^{\circ} \mathrm{C}$ for $5 \mathrm{~min}$. For each reaction $200 \mu \mathrm{MdNTPs} 20-40 \mathrm{ng}$ total-DNA and 200 $\mathrm{nM}$ of each primer were used. Cloning of the fragments was performed as described for $16 \mathrm{~S}$ rDNA Sequencing was performed by Eurofins MWG Operon.

\section{Experimental animals}

Twenty four healthy female Swiss albino mice weighing (18-22) g were used throughout this study. They were obtained from the National Institute of Cancer, Cairo University, Egypt and transferred to the Institute of Genetic Engineering and Biotechnology (GEBRI), Sadat University, Sadat City, Menoufia Province to be acclimatized for one week before experimentation in the animal houseunder the same environmental conditions. Mice were fed standard pellet and had free access to water during the experiment.

Mice were housed in individual standard isolation cages
$(45 \times 35 \times 25 \mathrm{~cm})$. Experiment was performed according to the Principles of Laboratory Animal care guidelines $(\mathrm{NIH}$, Guide 1985; Panigrahi et al., 2011).

\section{Tumor cells}

Ehrlich ascites carcinoma (EAC) cells (hyperdiploidsubline) was obtained from the National Institute of Cancer, Cairo University, Egypt, and has been propagated in our laboratory by weekly intraperitoneal (IP) inoculation of about $3 \times 10^{6}$ cells/mouse. Then; the ascites tumor cells obtained from donor mouse was diluted with saline solution (SS) and the viable EAC cells were counted with hemocytometer (Trypan blue indicator) under the microscope and were adjusted at $3 \times 10^{6}$ EAC cells $/ \mathrm{ml}$. Ascitic tumor cell counts were found to be more than $99 \%$ viable by the Trypan blue dye exclusion method. For induction of solid tumors; subcutaneous injection of $3 \times 10^{6}$ EAC cells per mouse was performed.

\section{In vitro study}

Cytotoxicity assay of Streptomyces extraction on Ehrlich ascites tumor cells and cell viability test were measured microscopically by calculating the viability of tumor cells. The optimal concentration of the bacterial extracts was estimated (Ag18 and Ag20). The viability percentage of tumor cells was measured after incubation with the tested extracts. According to (El-Merzabani et al., 1979); with some required modifications, the viability percentage of tumor cells were measured after incubation with the examined extracts (Ag18 and Ag20). A suspension of the tumor cells was attained from peritoneal cavities of tumorbearing mice and then diluted twice with buffered saline solution ( $\mathrm{pH}$ 7). In a set of sterile Eppendorf tubes; three sterile Eppendorf tubes; each containing $50 \mu 1$ of the diluted cell preparation was prepared; then add $150 \mu$ buffered saline solution in the first tube (control); $150 \mu \mathrm{l}$ of Ag18 was added to the diluted EAC cells in the second tube. Finally, $150 \mu \mathrm{l}$ of Ag20 was added to the prepared cell in the third tube. The three tubes were incubated in water bath at $38^{\circ} \mathrm{C}$ for 20 minutes. From each of the three tubes; $50 \mu 1$ of cell suspension was added to $50 \mu 1$ trypan blue and mixed in a new clean, dry and sterile Eppendorf tube, and then the number of living cells was calculated using a hemocytometer slide. Survival cells appeared as unstained bodies while non-viable cells stained blue. The percentagecytotoxicity was calculated using the formula, Percentagecytotoxicity $=100-T c-D c / T c \times 100$, where $T c=$ total EAC cells, and $D c=$ dead EAC cells.

\section{In vivo study}

The antitumor efficacy of Streptomyces extractions (AG18 \&AG20) was investigated in vivo on mice bearing solid tumors. A total of 24 female Swiss mice were divided into 4groups (six mice per group).Solid tumor was induced in all groups of study, except normal control group, by inoculation of mice with $3 \times 10^{6}$ EAC cells subcutaneously using female albino mice in their right thigh; the transplanted cells usually produce palpable tumors within a week. The volumes of the tumors of individual mouse were 
determined by measuring the length, width and depth of the tumors with a Vernier caliper according to the method of Papadopoulos et al., (1989).

\section{Grouping of animals}

The 24 female mice were divided randomly into 4 groups (6 animals per group):

Group I: Normal control - mice received sterile saline solution twice a week; through the subcutaneous injection; Group II:Tumor untreated - mice were inoculated subcutaneously with $3 \times 10^{6}$ EAC cells and leave without injection for one month;

Group III: Ag18 extract - mice were inoculated subcutaneously with $3 \times 10^{6}$ EAC cells then injected subcutaneously with Ag18 extract after solid tumor formation (7-10) days after tumor inoculation; at the site of tumor genesis; twice a week for one month.

Group IV: Ag20 extract - mice were inoculated subcutaneously with $3 \times 10^{6}$ EAC cells then injected subcutaneously with Ag20 extract after solid tumor formation (7-10) days after tumor inoculation; at the site of tumor genesis; twice a week for one month.

\section{Body weight}

The tumor weight of each mouse related to the four groups was recorded from the beginning of the experiment till one month. The weights were calculated as Mean \pm SD and the correlation between different groups was calculated using statistical analysis.

\section{Solid Tumor Volume}

Tumor was induced by injecting EAC cells $\left(3 \times 10^{6}\right.$ cells/ mouse) subcutaneously to the right hind limb of the mice for the groups(II, III and IV). The radii of the tumor were measured using Vernier Calipers at 5 days intervals for one month starting with 15 th day. The volume of the tumor was calculated using the formula $\mathrm{V}=4 / 3 \operatorname{IIr} 1^{2} \mathrm{r}^{2}$, where ' $\mathrm{r} 1$ ' and ' $r$ ' represent the major and minor diameter respectively (Atiaand Weiss, 1966).This was compared with tumor untreated (Group II).

\section{Histological studies}

For histological examination small samples were collected from the liver and kidney from each mouse of all groups, just after scarification of mice. All specimens were fixed in $10 \%$ neutral formalin, then processed for paraffin sections (5-7 microns) and stained with Harri'shaematoxylin and eosin (H\&E) according to Drury and Wallington (1980).Photomicrographs were taken using binocular digital microscope (Leica DMLB ${ }^{\circledR}$ ) with 3.2 mega pixels digital camera (Leica EC3) and program software (LASEZ. 1.6).

\section{Statistical analysis:}

The statistical significance of the experimental biochemical results was determined by the Student's t test (Murray, 1982). For all analysis, $\mathrm{p} \leq 0.05$ was accepted as significant probability level.

\section{Results}

\section{Isolation}

There was a high diversity of Streptomyces isolates in soils from the village ofTamalay- Menoufia Province Egypt.Under the shrubs and trees; rhizosphere of plants, agricultural soil and preserved areas. Pure isolates grew well on the differential agar media forming well isolated colonies. The isolates obtained formed colored tough, leathery and filamentous colonies that were hard to pick from the culture media, as a characteristic of actinomycetes and also produced colored pigments; which were secreted into the culture media within a few days of incubation. Twenty (20) isolates from actinomycetes were obtained but only two isolates of Streptomycetes have antitumor activity (Figs.1-4).

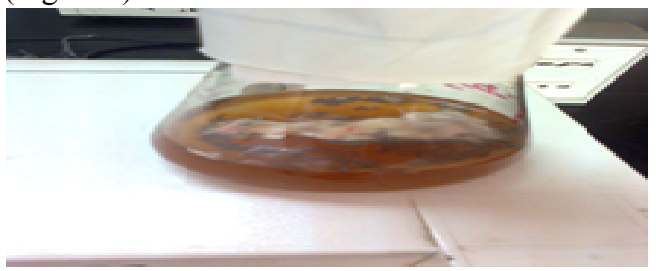

Fig.1.Streptomyces strain Ag18

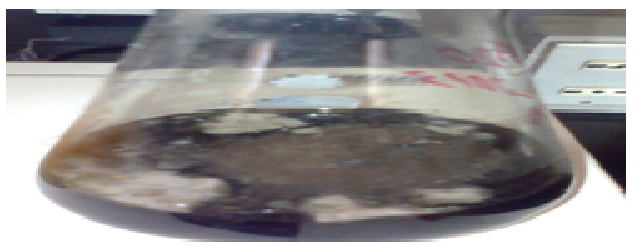

Fig.2. Streptomycesstrain Ag20

\section{Morphological and Physiological characteristics}

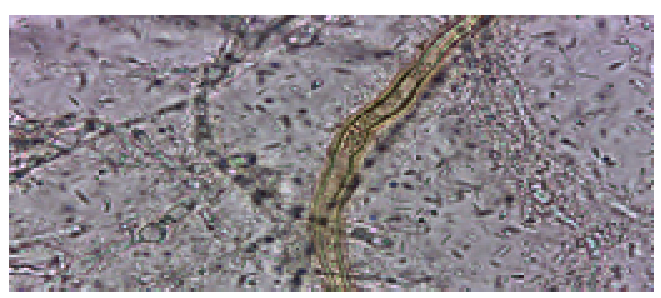

Fig.3. Morphology of aerial mycelia and spore chains of Streptomyces strain Ag18(X 1000).

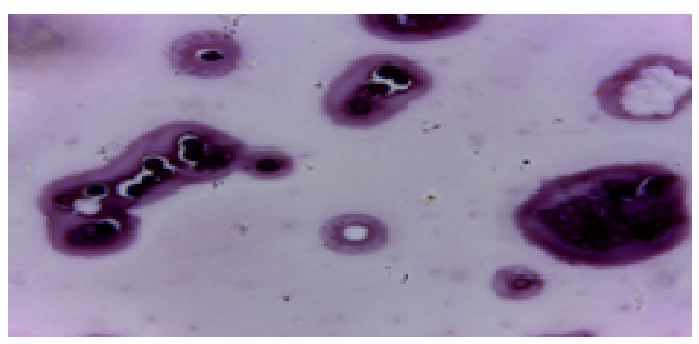

Fig.4. Morphology of aerial mycelia and spore chains of Streptomyces strain Ag20(X 1000). 
The morphological examination of these isolates, which have antitumor activity, indicates that they belong to the Streptomyces genus. The morphological and cultural characteristics of the Streptomyces isolates are shown in Table 1. The active isolates vary within two colors, with production of such compounds being recorded as a soluble pigment in the colors of brown-yellow and violet. The rate of melanin pigment production was $0 \%$. The color of the aerial mycelium was grey and violet. The reverse side color was brown-yellow and violet.

Table1.Morphological characterization of Streptomyces Strains, Ag18 and Ag20.

\begin{tabular}{|l|l|l|}
\hline \multicolumn{1}{|c|}{ Isolate } & \multicolumn{1}{|c|}{ Ag18 } & \multicolumn{1}{c|}{ Ag20 } \\
\hline $\begin{array}{l}\text { Aerial } \\
\text { mycelium }\end{array}$ & Grey & Violet \\
\hline $\begin{array}{l}\text { Reverse side } \\
\text { color }\end{array}$ & Brown yellow & Violet \\
\hline $\begin{array}{l}\text { Soluble } \\
\text { pigment color }\end{array}$ & Brown yellow & Violet \\
\hline $\begin{array}{l}\text { Spore } \\
\text { Surface }\end{array}$ & Smooth & Smooth \\
\hline $\begin{array}{l}\text { Sporophore } \\
\text { morphology }\end{array}$ & Spirales & Retinaculipeti \\
\hline
\end{tabular}

PCR amplification of PKS and NRPS-genes

Bacterial type I (modular) PKS gene fragments were amplified with the degenerate primers KSMAF and KSMB-R, which can be used to amplify $\beta$-ketoacyl synthase (KS) domain encoding fragments of ca $700 \mathrm{bp}$. PCR with these primers resulted in amplification of fragments of expected size from Streptomyces isolates, indicating their potential for production of polyketide secondary metabolites. Since PKS type I genes encode modular enzymes, and actinomycete strains usually contain

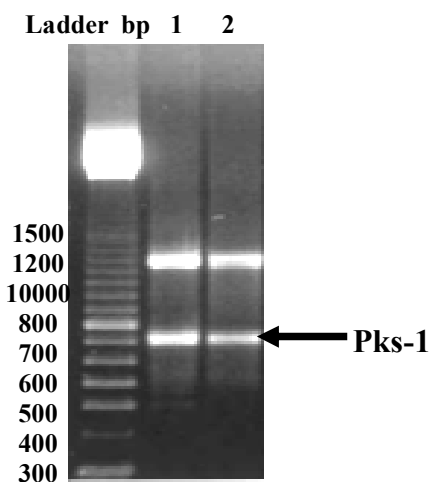

Fig.5. Agarose gel electrophoresis of PKS gene PCR products from gDNA of Streptomyces ambofaciens strain Ag20 (KF792054). more than one PKS gene cluster, it was expected that PCR products obtained with the KS-specific primers would represent mixtures of the KS-coding sequences. Therefore, sequencing of these gene fragments would be required for a better understanding of the diversity within the selected group of isolates and their dereplication.

\section{In vitro antitumor activity of Ag18 \& Ag20 on EAC:}

The Ehrlich ascites carcinoma cells appear bright (not colored) and intact in fig $\left(6_{\mathbf{a}}\right)$, On the other hand, in fig $\left(6_{\mathbf{b}}\right)$, Ehrlich ascites carcinoma cells treated with Ag18 appears to be colored with trypan blue. This also is shown in case of Ag20fig $\left(6_{c}\right)$. Animals bearing EAC cells treated with $\mathrm{Ag} 18$ and $\mathrm{Ag} 20$ showed a significant decrease in the total EAC cell count in comparison to non-treated tumor bearing animals.

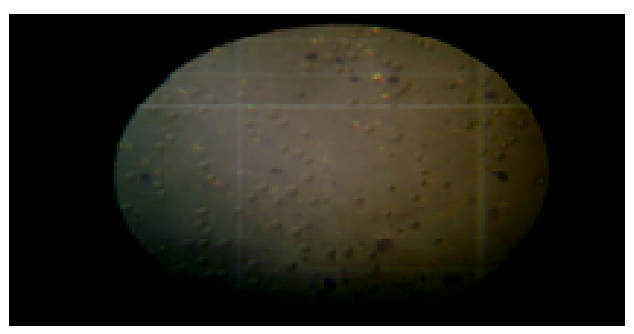

Fig.6a. Ehrlich ascites carcinoma cells without treatment.

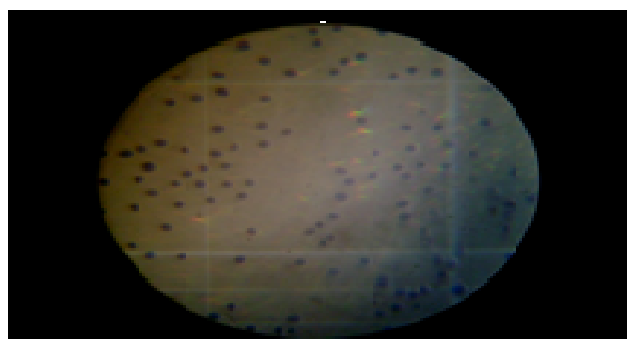

Fig.6b. Ehrlich ascites carcinoma cells treated with Ag18.

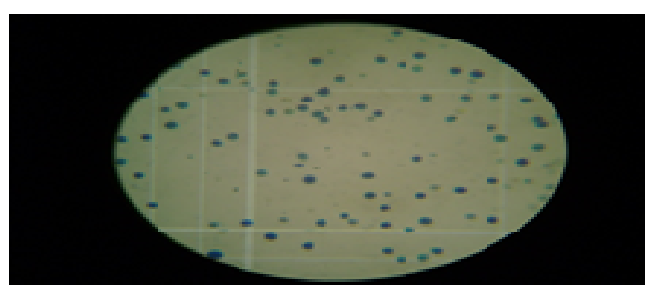

Fig.6. Ehrlich ascites carcinoma cells treatedwith Ag20.

In vivo antitumor activity of Ag18 \& Ag20 on solid tumors:

\section{1- Mice body weight:}

The weights of mice were different according to the group which is belonging to; the mice of tumor untreated group 
recorded elevated weights when compared to normal and distal convoluted tubules were normal. The glomerular control, Ag18 and Ag20 groups. Ag18 and Ag20 reduced capsule appeared normal with prominent glomerular space the weights of mice of the tumor untreated group in a very (Fig. 7).

highly significant change $(\mathrm{p}<0.001)$ towards the normal weights. This is obvious in Table 2 .

Liver:Control animals showed the normal structure of liver .The liver architecture formed from polygonal lobules. The outlines of the lobules were indistinct.The hepatocytes were arranged in cords that radiated out from the center of

Table (2): Effect of Streptomyces Ag18 and Ag20 on mice body weight.

\begin{tabular}{|l|c|}
\hline Groups & $\begin{array}{c}\text { Mice Body Weight (g) } \\
\text { Mean } \pm \text { SD }\end{array}$ \\
\hline Normal Control & $\mathbf{2 6 . 2 5} \pm \mathbf{2 . 2 1 7}$ \\
\hline Tumor Untreated & $\mathbf{3 7 . 2 5} \pm \mathbf{1 . 7 0 8}^{* * *}$ \\
\hline Tumor treated with Ag18 & $\mathbf{2 8 . 2 5} \pm \mathbf{1 . 7 0 8}$ \\
\hline Tumor treated with Ag20 & $\mathbf{2 8 . 2 5} \pm \mathbf{2 . 2 1 7 ^ { \mathbf { } }}$ \\
\hline
\end{tabular}

(***) Very Highly Significant $(\mathrm{p}<0.001)$ compared to normal control group.

(\$) Non- Significant $(p>0.05)$ compared to normal control group.

\section{2- Tumor size:}

In relation to the measurements of tumor size of the tumor untreated,tumor treated with Ag18and tumor treated with Ag20 groups, the recorded data showed that the Streptomyces extracts (Ag18\&Ag20) reduced the tumor volume in a very highly significant way $(\mathrm{p}<0.001)$. This effect is clear in (Table 3).

Table (3): Effect of Streptomyces Ag18 and Ag20 on tumor volume.

\begin{tabular}{|l|c|}
\hline Groups & $\begin{array}{c}\text { Tumor Volume } \\
\left(\mathbf{m m}^{\mathbf{3}}\right) \\
\text { Mean } \pm \text { SD }\end{array}$ \\
\hline $\begin{array}{l}\text { Tumor } \\
\text { Untreated }\end{array}$ & $\mathbf{4 . 1 7 5} \pm \mathbf{0 . 9 5 3 5}$ \\
\hline $\begin{array}{l}\text { Tumor } \\
\text { treated } \\
\text { with Ag18 }\end{array}$ & $\mathbf{0 . 7 0 5 0} \pm \mathbf{0 . 6 4 5 1}$ \\
\hline $\begin{array}{l}\text { Tumor } \\
\text { treated } \\
\text { with Ag20 }\end{array}$ & $\mathbf{0 . 6 4 7 5} \pm \mathbf{0 . 5 9 8 6}$ \\
\hline
\end{tabular}

$(* * *)$ Very Highly Significant $(\mathrm{p}<0.001)$ compared to tumor untreated group.

\section{Histological observations Control Group:}

Kidney: kidney of control animals formed of renal cortex and renal medulla. The renal corpuscles as well as proximal 


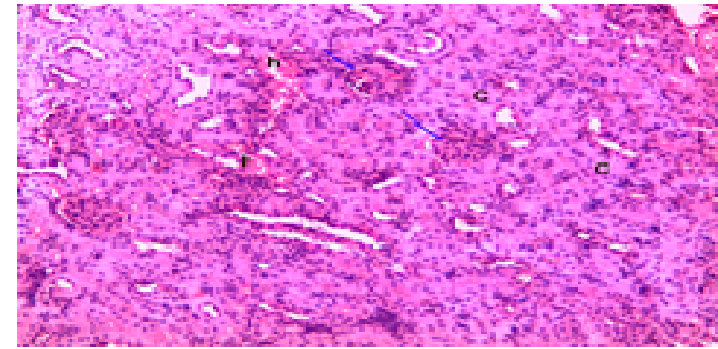

Fig.9. Photomicrograph of kidney of a mouse injected subcutaneously with EAC cells, showing: cloudy swelling (c), congested renal corpuscles with closed or very narrow glomerular space (arrow) and internal renal hemorrhage (h). H\&E X 200.

Liver: The histological structure of the liver showed lymphocytic cells invaded the liver tissue. The portal vein showed congestion and edema with invaded leucocytes with mononuclear cells. The hepatocytes showed degenerative changes as vacuolar degeneration and pyknosis. The hepatic cords as well as the hepatic sinusoids were indistinct (Fig. 10).

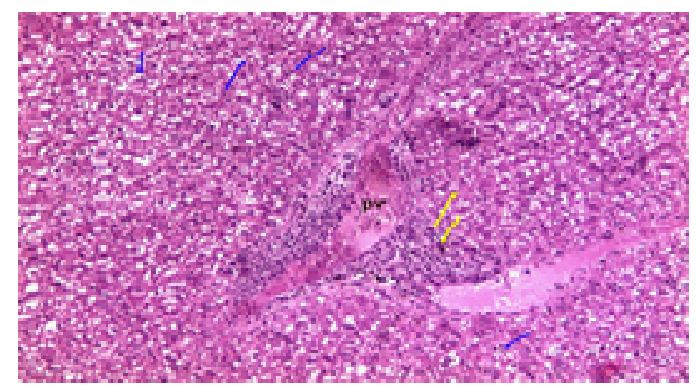

Fig.10. Photomicrograph of liver of a mouse injected subcutaneously with EAC cells, showing: congested portal vein (pv) surrounded by lymphocytic cells (yellow arrow) and degenerative changes in hepatocytes (blue arrow). Note: the hepatic cords not organized. H\&E X 200.

Group III: Mice injected subcutaneously with EAC cells, then after one week injected with Ag18 extract.

Kidney: The histological structure of the kidney still showed cloudy swelling of the renal tubules. The renal corpuscles appeared less congested with clear glomerular space. Both proximal and distal convoluted tubules showed prominent lumen, while the brush border of proximal tubules did not appeared (Fig. 11).

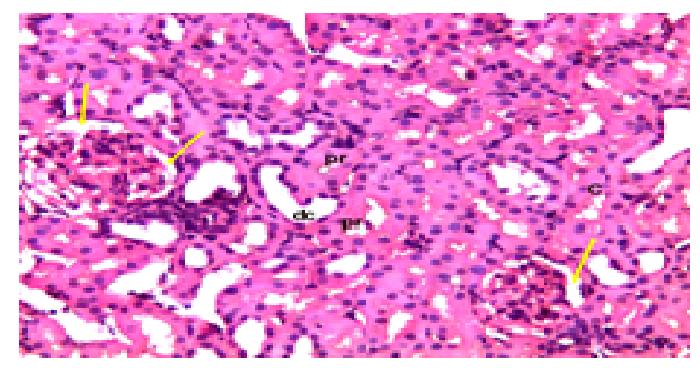

Fig.11. Photomicrograph of kidney of a mouse injected subcutaneously with EAC cells, then after one week injected with Ag18 extract showing: less prominent cloudy swelling (c), of renal tubules, Bowman's space reappeared (yellow arrows), proximal convoluted tubules (pr) and distal convoluted tubules (dc). H\&E X 200.

Liver: The histological structure of the liver showed that the lymphocytic cells appeared as fragments of different sizes and were presented toward the central vein. The congestion was decreased and the hepatocytes showed less degenerative changes and were resemble to normal structure. The hepatic cords as well as the hepatic sinusoids were distinct (Fig. 12).

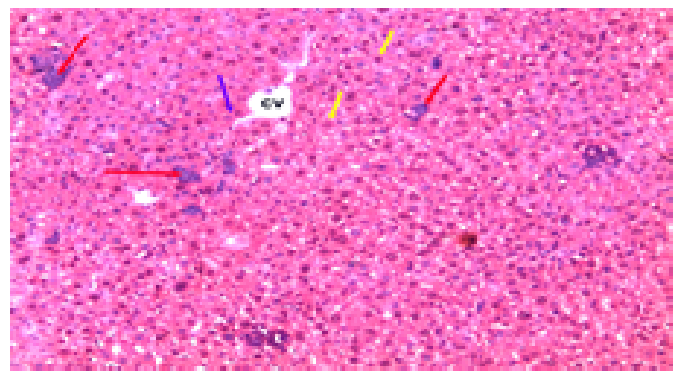

Fig.12. Photomicrograph of liver of a mouse injected subcutaneously with EAC cells, then after one week injected with $\operatorname{Ag} 18$ extract showing: central vein $(\mathrm{CV})$, the lymphocytic cells were decreased and appeared as fragments of different sizes (red arrows). The hepatocytes appeared normal (yellow arrows) and the hepatic cords reappeared (blue arrows) H\&E X 200.

\section{Group IV: Mice injected subcutaneously with EAC cells,} then after one week injected with Ag 20 extract.

Kidney: The histological structure of the kidney showed that the epithelia of the renal tubules appeared with few cloudy swelling. The renal corpuscles appeared with a decrease in congestion with clear glomerular space. Both proximal and distal convoluted tubules showed intact cells with prominent lumen, and the brush border of proximal tubules was obvious (Fig. 13).

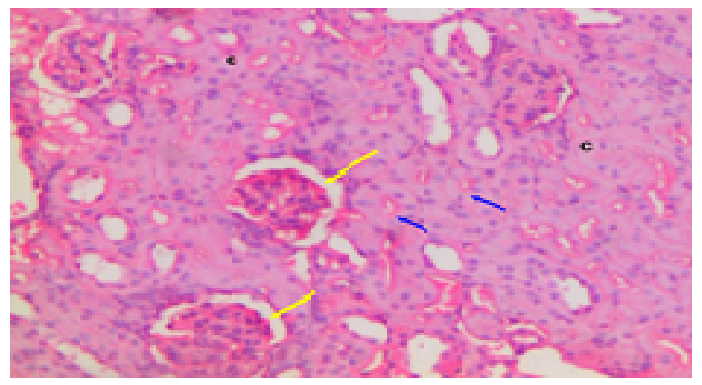

Fig.13. Photomicrograph of kidney of a mouse injected subcutaneously with EAC cells, then after one week injected with Ag 20 extract showing: reappearance of Bowman's space (yellow arrows), obvious proximal tubules (blue arrows) H\&E X 200.

Liver:The histological structure of the liver showed that the lymphocyticcells were greatly reduced in number and presented mainly in portal area. The hepatocytes in the central zone of hepatic lobule showed great improvement 
and appeared as normal. While the hepatocytes at the peripheral zone of hepatic lobule still showed cloudy swelling and degenerative changes. The architecture of hepatic cords appeared normal (Fig. 14).

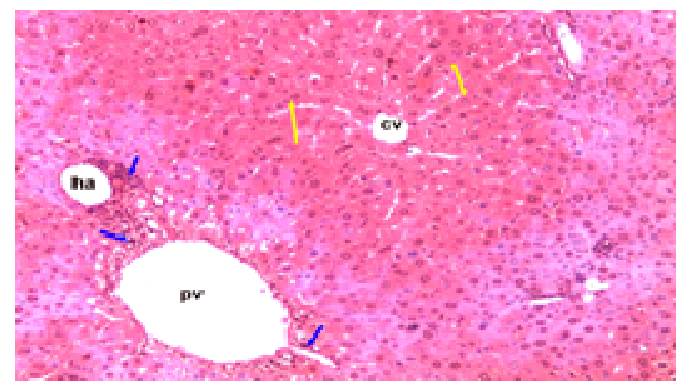

Fig.14. Photomicrograph of liver of a mouse injected subcutaneously with EAC cells, then after one week injected with Ag 20 extract showing: central vein (cv), portal vein (pv), hepatic artery (ha). The lymphocytic cells decreased specially in portal area (blue arrows), the hepatocytes surrounding central vein appeared normal with obvious hepatic cords (yellow arrows). H\&E X 200.

\section{Discussion}

The present study was carried out to evaluate theantitumor activity of metabolites from Streptomyces on EAC tumor bearing mice. Two isolates of Streptomyces extracts were obtained and used as antitumor agent against EAC. PCR amplification of fragments from Streptomyces isolates, indicating their potential for production of polyketide secondary metabolites(Izumikawa et al., 2006).Busti et al., (2006) stated that, since PKS type I genes encode modular enzymes, and actinomycete strains usually contain more than one PKS gene cluster, it was expected that PCR products obtained with the KS-specific primers would represent mixtures of the KS-coding sequences. Therefore, sequencing of these gene fragments would be required for a better understanding of the diversity within the selected group of isolates and their dereplication.

Ascites fluid is the direct nutritional source for tumor cells. So, a rapid increase in ascites fluid with tumor growth would be a mean to meet the nutritional requirement of tumor cells (Rajeshwar et al., 2005).

The EAC cells treated with Ag18 and Ag20 in vitro in this study appeared coloured with trypan blue. The blue colouration indicates to rupture of EAC cells membranes and the trypan blue pass through the broken membranes into the inside of cells. Thus we can suggest that the Streptomyces extracts (Ag18 \& Ag20) inhibited the EAC cell growth. This is greatly supported by the significant decrease in the number of viable cells and increase in dead cell population. Similar results have been reported (Gurkan et al., 1988; Prerona et al., 2011).

The mice body weights recorded very highly significant change as found in (table 2). This is in agreement with Altun and Ozalpan(2004); who proved that the inoculation of EAC cells into mice caused significant increase in the mice body weight after one month of inoculation. Such increase was due to accumulated ascites fluid of EAC in peritoneal cavity.

A very highly significant reduction in tumor volume was observed during experimentation in the treated mice compared to tumor untreated group (table3). The (Ag18 \& Ag20) Streptomyces extract administration reduced tumor volume indicating inhibition in the growth and multiplication of tumor cells which may be due to the decrease in the ascites fluid acting as a direct nutritional source or the presence of compounds inhibiting mitosis, DNA synthesis or replication via enzyme pathways. This finding is concomitance with Banu et al., (2011).

The histological structure of kidney of mice injected subcutaneously with EAC cells showed degenerative changes as cloudy swelling of the renal tubules. Also renal corpuscles appeared congested. Some areas showed internal hemorrhage. The same changes were observed by (Holdaas, et al., 1985) and (Abd El-Wahab, \&Fouda, 2009), who concluded that, the congestion and areas of interstitial haemorrhage may lie in the weakness of the renal parenchymal tissue as a result of the degenerative changes. These structural changes reflect upon one or more of the principal functions of the kidneys, which include volume regulation, acid base balance, electrolyte balance, excretion of waste products and endocrine functions including the elaboration of rennin and erythropoietin (Cotran, 1987).The histological structure of kidney of mice injected subcutaneously with EAC cells showed degenerative changes.

The histological structure of the liver showed lymphocytic cells invaded the liver tissue. The portal vein showed congestion and edema with invaded leucocytes with mononuclear cells. The hepatocytes showed degenerative changes as vacuolar degeneration and pyknosis. The hepatic cords as well as the hepatic sinusoids were indistinct. The same degenerative changes were reported by (Fouda, 2005; Bhattacharyya, et al., 2007 and Chakraborty, et al., 2007; Abd El-Wahab, \&Fouda, 2009). This may be due to the accumulation of haemorrhagic ascetic fluid within the peritoneal cavity in which the cells proliferate and move to invade the internal organs (Chakraborty, et al., 2007).

The histological picture of both kidney and liver of mice injected with EAC cells, then after one week injected with Ag18 or Ag20 showed less degenerative changes and decreased congestion. The cells were appeared resemble to normal structure. The same results were mentioned by (Fouda, 2005; and Abd El-Wahab, \&Fouda, 2009) using tetradotoxin as antitumor.

A reliable criterion for judging the value of any anticanceragents is the prolongation of life span of animals (Hogland, 1982). A decrease of degenerative changes in 
both kidney and liver in vivo as well as decrease of viable tumor cell count in vitro, as mentioned above, reduced the tumor cells and increase the life span of EAC tumor bearing mice.

In conclusion, the present study showed that the Streptomyces extracts (Ag18 \& Ag20) reduced the tumor cells and increased the life span of EAC tumor bearing mice. These suggest that Streptomyces extracts (Ag18 \& Ag20) exhibits potential antitumor activities.

\section{References}

Abd El-Wahab; Samia M ,Fouda; Fatma M (2009).Histological and histochemical study on the effect of Ehrlich ascites carcinoma on the liver and kidney of mice and the possible protective role of tetrodotoxin. Egyptian Journal of Biology, 11:13-25.

Altun, S. and Ozalpan, O (2004).Interactive regeneration of liver and growth of Ehrlich ascites tumor in mice.Biologia, Bratislava, 59(3): 375- 382

Atia, M.A, and Weiss D.W, (1966).Immunology of spontaneous mammary carcinomas in mice. Acquired tumor resistance and enhancement in strain A mice infected with mammary tumor virus, Cancer Res., 26:1887-1900.

Azambuja, E., J.F. Fleck, R.G. Batista, S.S.M. Barreto. (2005).Bleomycin lung toxicity: who are the patients with increased risk? Pulmonary Pharmacology and Therapeutics, 18(5): 363-366.

BanuRekha J. and Jayakar B., (2011). Anti-cancer activity of ethanolic extract of leaves of Plumeriarubra (Linn).,Curr. Pharm. Res., 1:175-179.

Bernan VS, Greenstein M, Carter GT. (2004).Mining marine microorganisms as a source of new antimicrobials and antifungals.Curr Med Chem Anti-Infective Agents.; 3:181-195.

Bhattacharyya A, Mandal D, Lahiry L, Bhattacharyya S, Chattopadhyay S, Ghosh UK, Sa G, Das T (2007).Black tea-induced amelioration of hepatic oxidative stress through antioxidative activity in EAC-bearing mice. Journal of Environmental Pathology Toxicology \& Oncology 26 (4): 245-254.

Busti, E., Monciardini, P., Cavaletti, L., Bamonte, R.,Lazzarini, A.; Sosio, M.; Donadio, S. (2006). Antibioticproducing ability by representatives of a newly discovered lineage of actinomycetes.Microbiol., 152(Pt 3): 675-683.

Chakraborty T, Bhuniya D, Chatterjee M, Rahaman M, Singha D, Chatterjee BN, Datta S, Rana A, Samanta K, Srivastawa S, Maitra S K \&Chatterjee M (2007). Acanthus ilicifolius plant extract prevents DNA alterations in a transplantable Ehrlich ascites carcinoma- bearing murine model. World Journal of Gastroenterology 13 (48): 65386548.
Cotran R (1987). The kidney and its collecting system. Chapter 14 in Robbins \& Kumar (eds) Basic Pathology, W. B. Saunders Company, London, Philadelphia.

Demain AL, Davies E J (1999). Manual of Industrial Microbiology and Biotechnology.2nd Edition.American Society of Microbiology.

Drury R. A. B. and Wallington E. A. (1980).Carlcton's Histological technique 5th ed. Oxford University presses. London. New York, Toronto.

El-Merzabani MM, El-Aaser AA, Attia MAM, ElDuweini AK, Ghazal AH (1979). Screening system for Egyptian Plants with Potential Antitumor Activity.J.Planta Medica36:150-155.

Fouda FM (2005). Anti-tumor activity of tetrodotoxin extracted from the Masked Puffer fish Arothrondiadematus. Egyptian Journal of Biology 7: 1-13.

Goodfellow M, Williams ST. (1983). Ecology of actinomycetes.Annu Rev Microbiol.; 37:189-216.

Gupta A, Mazumder UK, Kumar RS \& Kumar TS (2004).Anti-tumour activity and anti-oxidant role of Bauhinia racemosa against Ehrlich ascites carcinoma in Swiss albino mice. Acta Pharmacologia Sinica 25: 10701076.

Gurkan k, Cem A., Tuncay,A., Sevim D. (1988). The Antitumor Effect of Bleomycin Combined with Bestatin against Ehrlich Ascites Carcinoma in Mice. Proceedings of the Society for Experimental Biology and Medicine 187:292-295.

Hogland HC (1982).Hematological complications of cancerchemotherapy. Semi Oncol; 9: 95-102.

Holdaas H, Kopp UC ,Dibona GF (1985). Modulation of relex renal vasoconstriction by increased endogenous renal postaglandine synthesis. Journal of Pharmacology \& Experimental Therapeutics 232: 332-371.

Innis, MA, Gelfand, DH, Sninsky, JJ, White, TJ (1990).PCR Protocols.A Guide to Methods and Applications.Academic Press San Diego.

Izumikawa, M.; Murata, M.; Tachibana, K.; Ebizuka, Y.; Fujii, I. (2003).Cloning of modular type I polyketide synthase genes from salinomycin producing strain of Streptomyces albus. Bioorganic \& Medicinal Chem., 11, 3401-3405.

Khamna S, Yokota A, Lumyong S (2009). LAsparaginase production by actinomycetes isolated from some Thai medicinal plant rhizosphere soils. Int. J. Integr. Biol. 6(1):22-26. 
Kumar MS, Selvam K (2011).Isolation and purification of high efficiency L-asparaginase by quantitative preparative continuous elution SDS PAGE electrophoresis. J. Microb. Biochem. Technol. 3(5):073083.

Maxwell SR (1995). Prospects for the use of antioxidant therapies. Drugs 49:345-361. McCarthy AJ, Williams ST. (1992). Actinomycetes as
agents of biodegradation in the environment-a review.Gene; 115:189-192.

McDaniel, R., Kao, C.M., Hwang, S.J. \&Khosla, C. (1997).Engineered intermodular and intramodularpolyketide synthase fusions.Chem. Biol. 4, 667-674.

Mueller, U.G. and G. Nicole. (2002). Fungus farming insects: multiple origins and diverse evolutionary histories. Sectionof Integrative Biology, 99: 15247-15249. NIH, Guide, for the use of laboratory Animals, NIH actinomycetes. Chemosphere; 32:1427-1434. Publications, (1985). No $85-23$.

Panigrahi B.B, Panda P.K,Patro V.J, (2011). Antitumor and in vivo antioxidant activities of Pandanusodori tissimuslinn against ehrlighassites carcinoma in Swiss albino mice, 8, ( 2), May - June; Article-034.

PreronaSaha, U. Mazumder, K. . Haldar, P. K Sagar, N., Sriparna, K., Asis B., Biswakanth K. (2011). Anticancer activity of methanol extract of Cucurbita maxima against Ehrlich as-cites carcinoma. U. K. Mazumderet al., Int. J. Res. Pharm. Sci., 2(1), 52-59.

Rajeshwar, Y., Gupta, M., Mazumder, U.K. (2005).Antitumor activity and in vivo antioxidant status of Mucunapruriens (Fabaceae) seeds against Ehrlich ascites carcinoma in Swiss albino mice.Iranian J Pharmaco.Ther; 4:46-53.
Savitri NA, Azmi W (2003). Microbial L-asparaginase: A potent antitumour enzyme. Ind. J. Biotechnol. 2:184-194.

Schrempf H. (2001). Recognition and degradation of chitin by streptomycetes.Antonie van Leeuwenhoek.; 79:285-289.

Shirling, E.B. and D. Gottlieb, (1966).Methods for characterization of Streptomyces species. Int. J. Syst. Bacteriol., 16: 313- 340.

Stach JE, Bull AT. (2005). Estimating and comparing the diversity of marine actinobacteria. Antonie van Leeuwenhoek.; 87:3-9.

Ventura M, Canchaya C, Tauch A, Chandra G, Fitzgerald GF, Chater KF, van Sinderen D. (2007). Genomics of Actinobacteria: Tracing the evolutionary history of an ancient phylum. MicrobiolMolBiol Rev.; 71:495-548.

Wilkins K. (1996).Volatile metabolites from 